Arhe XVII, 33/2020

UDK 130.123.1 Jameson F.

130.123.1 Hegel G.

130.123.1 Marx K.

DOI https://doi.org/10.19090/arhe.2020.33.85-104

Originalni naučni rad

Original Scientific Article

\author{
NEVENA JEVTIĆ ${ }^{1}$ \\ Univerzitet u Novom Sadu, Filozofski fakultet
}

\title{
KONCEPT DIJALEKTIČKE KRITIKE FREDRIKA DŽEJMSONA
}

Sažetak: Rad nastoji da prikaže osnovnu strukturu Džejmsonovog koncepta dijalektičke kritike onako kako je on razvijen u delima Marksizam i forma i Političko nesvesno. Namera rada je da se pruži analiza svojevrsnog konstitutivnog dualizma, na osnovu koga Džejmson prilazi tradiciji dijalektičkog mišljenja, poput „filozofija - istorija“, „hegelijanstvo - marksizam“, „kritika - razumevanje“, te njegovog ukidanja. Polazeći od činjenice izvanredne analitičke moći ovog koncepta, rad nastoji da afirmiše Džejmsonov projekat revitalizovanja kritike kao neprevaziđenog načina marksističke intervencije unutar sveta kasnog kapitalizma.

Ključne reči: zapadni marksizam, dijalektička kritika, Džejmson, Hegel, Marks

\section{UVOD}

Glavni argument studije o zapadnom marksizmu Perija Andersona (Razmatranje o zapadnom marksizmu, 1976) jeste da je pomeranje fokusa marksizma s tradicionalnog polja ekonomije na sferu kulture i politike nešto što je bilo uslovljeno samom konfiguracijom istorijskih, društveno političkih faktora koje u širokim obrisima opisuje njegova studija. Detaljna istorija tih faktora prevazilazi prostor ovog članka, tako da ovom prilikom mora biti dovoljan samo kratak osvrt na glavne tokove Andersonove analize. Nakon što je radnički pokret, kao i teorijsko jedinstvo i internacionalizam marksizma u Evropi, nošeno

\footnotetext{
${ }^{1}$ E-mail adresa autorke: nevena.jevtic@ff.uns.ac.rs
} 
Drugom internacionalom, rascepljen izbijanjem Prvog svetskog rata, naredni odlučujući događaj u ovom periodu svakako je Oktobarska revolucija u Rusiji. Međutim, u ostatku Evrope ovaj talas proleterske revolucije biva odsečen, zaustavljen. Anderson kaže: „Pokazalo se da je svuda sem u Rusiji kapital bio odlučujuće snažniji“‘2. Iako je radnička klasa pretrpela poraz, zahvaljujući konsolidovanju Treće internacionale i nacionalnih komunističkih partija, ona ostaje snažna pretnja vladajućim klasama u Centralnoj i Istočnoj Evropi. Nakon kataklizmične 1929. godine, krah kapitalizma pratio je narastajući talas nezaposlenosti i društvenih antagonizama. „Društvena kontra-revolucija u svojim najbrutalnijim i najnasilnijim formama, ukidanjem parlamentarne demokratije u sve jednoj za drugom zemljom, sada je mobilisana da odstrani svaku autonomnu organizaciju radničke klase“33. Fašističke diktature izrastaju u ovom kontekstu upravo kao odgovor na intenziviranje klasne borbe i pretnje vladajućem poretku od strane radničkog pokreta Evrope. Do izbijanja Drugog svetskog rata, političkom represijom i ubistvima organizaciono tkivo radničkog pokreta bilo je $u$ pojedinim delovima Evrope ozbiljno oslabljeno, a s izbijanjem rata ono je dobrim delom demolirano u Nemačkoj. Po završetku Drugog svetskog rata, pobedom Crvene armije nad Vermahtom, oslobođenjem Evrope od nacističkog terora zahvaljujući njenim ogromnim ljudskim žrtvama, konsoliduje se u narednom periodu socijalistički blok koji se prostirao na skoro pola kontinenta. Narednih 20 godina karakteriše stabilnost parlamentarne demokratije u kapitalističkim zemljama zapadne Evrope kao i dalekosežna ekspanzija kapitalizma, s jedne strane, dok s druge represivni birokratski režimi pod pokroviteljstvom SSSR prolaze kroz periodične krize koje prate relativno uzlazan ekonomski razvoj. „U ovom izmenjenom univerzumu revolucionarna teorija je dovršila mutiranje koje je proizvelo ono što se danas retrospektivno naziva 'zapadnim marksizmom ${ }^{\prime}$ '4

U ovoj studiji Anderson nije Fredrika Džejmsona eksplicitno svrstao u tradiciju marksističkih autora koji se javljaju nakon Prvog

\footnotetext{
${ }^{2}$ Perry Anderson, Consideration of Western Marxism, p. 15.

${ }^{3}$ Op. cit., p. 20.

${ }^{4}$ Op. cit., p. 25.
} 
svetskog rata. Ovi su autori poreklom iz sličnog društvenog miljea kao sinovi industrijalaca, bankara i državnih činovnika (izuzev jednog slučaja), čija su filozofska interesovanja, koliko god svojevrsna, bila obeležena zajedničkim karakteristikama. Kao predstavnike ove tradicije Anderson navodi: Lukača, Korša, Gramšija, Benjamina, Horkhajmera, Dela Volpea, Markuzea, Lefevra, Adorna, Sartra, Altisera i Koletija. U njihovim rukama, kako on kaže, ,marksizam je postao tip teorije koji se u određenim kritičkim aspektima sasvim razlikovao od svega što mu je prethodilo“5. Kao prvu i najizrazitiju karakteristiku ove tradicije Anderson navodi „strukturni razvod“ teorije i političke prakse ${ }^{6}$. Ona se jasno vidi pri poređenju i sa starom i sa novijom „klasičnom“ generacijom predratnih marksista podjednako (Labriola, Mering, Kautski, Plehanov, a posebno Lenjin, Luksemburg, Trocki, Hilferding, Bauer, Bukarin itd.), čiji je istraživački interes i političku praksu karakterisalo upravo suprotno stanje stvari. Njihov teorijski rad se odvijao u ključu snažnog jedinstva teorije i prakse, budući da su ove individue bile veoma aktivne u radničkim partijama istočne i centralne Evrope. Međutim, sudbina političkog života tri fundamentalne ličnosti, koje je Anderson izdvojio kao ,prave začetnike celokupnog obrasca zapadnog marksizma“ - Lukač, Korš i Gramši, govori veoma jasno o postojanju onih snaga koje će vremenom razdvojiti marksističku teoriju od bilo kakve klasne prakse $^{7}$. Marginalizacija, (auto)cenzura, progonstvo, izolacija - neke su od istaknutih odlika te sudbine koja ih je vodila ka skoro identičnom ishodu, odnosno njihovom udaljavanju od masovnog pokreta i okretanju filozofiji i književnoj kritici. Ovaj proces duboke promene i depolitizacije dobiće i institucionalizovani izraz u Nemačkoj, sa snažnim zamahom nakon Drugog svetskog rata, sa Frankfurtskom kritičkom školom. U Francuskoj i Italiji, takođe, situacija će - uz sve specifičnosti i razlike u vezi s postojećim organizacionim formama i teorijskim nasleđem marksizma - biti određena ovom transformacijom i odvajanjem teorijskog rada od oficijelne politike partije ili revolucionarne politike uopšte. „Tako je skriveni žig zapadnog marksizma kao celine to da je on

\footnotetext{
${ }^{5}$ Loc. cit.

${ }^{6}$ Op. cit., p. 29.

${ }^{7}$ Op. cit., p. 30.
} 
proizvod poraza. Neuspeh socijalističke revolucije da se proširi izvan Rusije, uzrok i posledica njene korupcije unutar Rusije, jeste zajednička pozadina celokupne teorijske tradicije ovog perioda. Njena glavna dela su bez izuzetka nastala u situacijama političke izolacije i očaja ‘8 .

Međutim, u kasnijoj studiji Izvori postmodernosti (1998), Anderson će ne samo izričito svrstati Fredrika Džejmsona među gore pomenute mislioce, nego će u njemu videti čak i kulminaciju tradicije zapadnog marksizma ${ }^{9}$. To izgleda kao sasvim prikladan i prirodan korak, kada se uzmu u obzir osnovni parametri Džejmsonovog teorijskog rada. Pošto je veoma lako uočljivo da Džejmson operiše na stanovištu svesti o uslovljenosti misli uopšte društvenom i istorijskom realnosti, lako se vidi $\mathrm{i}$ to da je taj stav kod njega zapravo razvijen $\mathrm{u}$ jedan celovit interpretativni program. Ovaj program u sebi objedinjuje i povezuje sve ključne karakteristike tradicije zapadnog marksizma i tako ih iz implicitne pozadine pojedinačnih učenja njenih predstavnika dovodi do svesti „na drugoj potenciji“"10, kako sam Džejmson objašnjava vlastitu dijalektičku kritičku metodu. Anderson tvrdi: „Od Lukača, Džejmson je preuzeo njegovu predanost periodizaciji i fascinaciju narativom; od Bloha, poštovanje prema nadama i snovima skrivenim unutar obezvređenog objekt-sveta; od Sartra, izvanrednu fluentnost u teksturama neposrednog iskustva; od Lefevra, znatiželju u vezi s urbanim prostorom; od Altisera, pozitivnu koncepciju ideologije, kao nužnog društvenog imaginarija; od Adorna, ambiciju da predstavi totalnost svog objekta kao ništa manje nego 'metaforičku kompoziciju'“11. Obiman repertoar interesovanja i problema, koji je rezultat interpretativne kristalizacije učenja ključnih autora zapadnog marksizma, svedoči i o Džejmsonovoj primeni vlastitog metoda na istorijski kontekst i zadatke svoga učenja. Rezultat nije tek sinkretički kolaž, već jedna veoma sugestivna sinteza ${ }^{12}$.

\footnotetext{
${ }^{8}$ Op. cit., p. 42.

${ }^{9}$ Perry Anderson, The Origins of postmodernity, p. 71.

${ }^{10}$ Fredrik Džejmson, Marksizam i forma, str. 343.

${ }^{11}$ Perry Anderson, The Origins of postmodernity, p. 71.

${ }^{12}$ Poređenja radi, Kuvelakis će oceniti, ne nužno negativno, ovu obimnost baš kao „bezgranični sinkretizam“: „Ono sa čime imamo posla u Džejmsonovom slučaju, pre nego s ekspozicijom doktrine ili sistema, jeste operacija ogromne interpretativne mašine, koja je sposobna da „svari“ skoro bilo šta, ili
} 
Ta sinteza, međutim, ne bi bila ubedljiva ukoliko bi njen princip počivao na prostom odabiru „nasleđenih kategorija“ prema vanjskoj proceni njihove plauzibilnosti ili korisnosti. Mada je nemoguće u potpunosti isključiti mogućnost da je $\mathrm{i}$ to $\mathrm{u}$ izvesnoj meri igralo ulogu, ipak Džejmsonova dijalektička kritika zahteva da dobijeni rezultat organski, a ne isključivo negativno kritički, izraste iz materijala ili tendencija koje mu prethode.

Iako bi se značaj Džejmsonove filozofije za savremenu filozofsku diskusiju mogao procenjivati prema njenim brojnim zaslugama, posebno se ističe sledeći par: u sučeljavanju s različitim misaonim stilovima postmodernizma (strukturalizma, dekonstruktivizma, neohistoricizma) i njihovoj rastućoj popularnosti u svetskim intelektualnim krugovima, koje je shvatio kao samu „logiku kasnog kapitalizma“, Džejmson utemeljuje ovu logiku kao specifičnu društvenu formu. Zapravo, on istrajava u afirmaciji marksizma kao jedinog suštinski „velikog narativa“ (koji može prodreti u uslove produkcije ,narativa“ uopšte kao kulturnih artefakata) i to onog čija je fundamentalna odlika upravo neprevladivost. U svom kapitalnom delu Političko nesvesno on tvrdi: „Marksizam se danas ne može braniti samo kao zamena za te druge metode, s time da se ovi onda trijumfalno otprave na đubrište istorije; ti metodi imaju ipak autoriteta, po tome što verno odgovaraju ovom ili onom lokalnom zakonu rasparčanog društvenog života, ovom ili onom podsistemu složene i poput gljiva razrasle kulturne nadgradnje. Marksizam je ovde, u duhu jedne istinskije dijalektičke tradicije, shvaćen kao onaj 'neprelazni horizont' koji obuhvata takve na izgled antagonističke ili nesamerljive kritičke operacije, dodeljujući im nesumnjivu sektorsku vrednost unutar sebe, čime ih istovremeno i poništava i očuvava“"13. Konačno, nasuprot značajnoj tendenciji unutar samog marksističkog tabora 20. veka, on insistira na vitalnosti kritike kao neprevaziđenog modusa marksističke intervencije unutar sveta kulturne

alternativno, nešto poput nezasite ,žudnje za teorijom“, nošene čini se samo bezgraničnim sinkretizmom u kombinaciji s intelektualnom znatiželjom čiji je raspon bez premca u istoriji kulturnih studija“, S. Kouvelakis, (J. Bidet ed.) Critical Companion to Contemporary Marxism, p. 698 - 699.

${ }^{13}$ Fredrik Džejmson, Političko nesvesno, str. 8. 
produkcije kasnog kapitalizma. Ovaj članak će nastojati da ukaže na neke tehničke elemente ,interpretativne mašine“ Džejmsonove dijalektičke kritike koji bacaju svetlo na način na koji on razume međusobni odnos i razrešenje izvornih elemenata tradicije dijalektičkog mišljenja. Detaljna analiza načina na koji se ovaj autor odnosi prema svojim filozofskim savremenicima mora, međutim, biti ostavljena po strani kao tema jednog posebnog rada.

\section{HEGELIJANSKA KRITIKA I ILUZIJA AUTONOMNOSTI SVESTI}

Prva rečenica kojom Džejmson otpočinje knjigu Postmodernizam ili kulturna logika kasnog kapitalizma daje sada već dobro poznatu definiciju postmodernizma: „Najsigurnije je shvatiti pojam postmodernizma kao pokušaj da se sadašnjost misli istorijski u doba koje je pre svega zaboravilo da misli istorijski“"14. Dijagnoza ovog „privilegovanog simptoma“ gubitka istoričnosti je prevashodno poslužila Džejmsonu da povuče demarkacionu liniju između „njih“ i „nas“. Naime, Džejmson se pozicionira nasuprot ovog gubitka, koji mu je morao biti transparentan i ranije, odnosno u vreme kada piše Političko nesvesno, gde formuliše „imperativ“ svog kritičkog stanovišta upravo insistirajući na primatu istorije: „Uvek istorizujte! Ta parola - jedini apsolutni i mogli bismo čak reći 'transistorijski' imperativ svakog dijalektičkog mišljenja“"15. Ovaj imperativ istorizacije predstavlja srž njegovog „revitalizovanja“ kritike uopšte. U osnovi presahlih političkih energija različitih postmodernih ,interpretacija“ pokazuje se jedinstven unutrašnji sistem drenaže - pokušaj kontekstualizovanja vlastitih istorijskih uslova i mogućnosti bez posezanja za istorijskom perspektivom koja je prokažena kao „problematična“. Iscrpljene političke energije zapravo se okreću filozofijama koje nisu u stanju da prikažu totalitet. Radikalni politički programi menjaju se za „radikalne“ filozofske projekte. Pogotovo u slučaju kada pokušavaju da sebe definišu kao „teoriju postmodernizma, oni se pokazuju zapravo kao „nastojanje da se izmeri temperatura epohe

\footnotetext{
${ }^{14}$ Fredric Jameson, Postmodernism or The Cultural Logic of Late Capitalism, p. IX.

${ }^{15}$ Fredrik Džejmson, Političko nesvesno, str. 7.
} 
bez instrumenata i u situaciji u kojoj nismo čak sigurni da i dalje postoji nešto tako koherentno poput 'epohe', zeitgeist-a ili 'sistema' ili 'tekuće situacije'. Teorija postmodernizma je stoga dijalektička barem utoliko što ima pameti da se uhvati za tu samu nesigurnost kao prvi nagoveštaj i da se drži za vlastitu Arijadninu nit na svom putu kroz ono što se lako može pokazati uopšte ne kao lavirint, već gulag ili možda tržni centar“16.

Svojevrsna „naivnost“ karakteriše postmodernističke narative, smatra Džejmson, a ona je očigledna s obzirom na „ovaj nepredvidivi povratak narativa kao narativa o kraju narativa, ovaj povratak istorije usred prognoze o propasti istorijskog telosa ${ }^{\text {“17 }}$. Naivnost koja se raspršuje i gubi - predstavlja u tradicionalnom smislu način na koji je opisivan efekat kritike, pogotovo kao efekat napredovanja u dijalektičkom mišljenju onako kako to stoji na primer kod Hegela. Za ovog mislioca, naivnost je prevashodno karakteristika običnog, svakodnevnog mišljenja. Filozofska svest počiva na intenzivnom iskustvu gubitka te naivnosti obične svesti. Tačnije, to iskustvo gubitka predstavlja razliku između obične i filozofske svesti. Ovu hegelijansku proceduru kritike Džejmson analizira u delu Marksizam i forma. Njegova analiza polazi od činjenice da je svakodnevna, obična svest kod Hegela bila predstavljena u svoja dva snažna lika - zdrav razum i apstraktno mišljenje. Unutar Hegelovog opusa, dijalektička kritika je bila uperena čas protiv jednog, čas protiv drugog lika. U zavisnosti od svog temeljnog usmerenja, filozofska svest, odnosno dijalektička kritika, odvijala bi se proceduralno drugačije. U borbi protiv zdravog razuma, ona se pokazuje kao nešto „preterano složeno i istančano“, dok je u borbi protiv apstraktnog mišljenja ona ono najprostije, skoro pa surovo u svom pojednostavljivanju ${ }^{18}$. Bez obzira na

\footnotetext{
${ }^{16}$ Fredric Jameson, Postmodernism or The Cultural Logic of Late Capitalism, p. $\mathrm{XI}$.

${ }^{17}$ Op. cit., p. XII.

${ }^{18}$ Fredrik Džejmson, Marksizam i forma, str. 312 - 313. U nastavku Džejmson kaže: „U stvari, ta dva prividno suprotna efekta dijalektičke svesti u mnogome odgovaraju, kao što ćemo kasnije videti, dijalektici hegelovstva i marksizma“ (Op. cit, str. 313). Ovakav odnos „hegelijanstva i marksizma“, postojanje dijalektike (a zašto je ne bi bilo?) između ove dve filozofske pozicije, ima ogromnu heurističku moć. Njihova dijalektika ili logika unutrašnjeg razvoja kategorija koje pripadaju ovim „filozofskim sistemima“, trebalo bi da bude
} 
to na koji se konkretno način slama naivnost početnog polazišta, jedno je za Džejmsona jasno: „Bez tog trenutka preobražaja, bez tog početnog svesnog prevazilaženja starijeg, naivnog stava, ne može biti reči o istinskom dijalektičkom osvešćenju“"19.

Na ovom mestu se može najbolje videti način na koji se, prema Džejmsonu, marksizam odnosi spram drugih „teorija“. Dijalektički proces istorije svedoči o tome da postoji jedan ultimativni interpretativni model, stoga se marksizam i ovom „objektivnom“ stranom, „redom stvari“, potvrđuje kao taj integralni, neprevladivi horizont koji jedini svojom hermeneutičkom „plodnošću i gustinom“ uspeva da postigne „totalizujući ideal razumevanja“620. S obzirom na strukturni manjak u vidu aistoričnosti polazišta onih filozofskih projekata koji nastoje da se ograde ili odrede spram istorije, dijalektičko mišljenje poseduje kritičke instrumente kojima se može realizovati i dovršiti i njihovo neuspelo poniranje u sebe. Međutim, pitanje koje se nameće jeste kakvo razumevanje ciljeva marksizma proizilazi iz te operacije dijalektičkog mišljenja?

Ne znači naravno da je to bila autorova namera, ali sledeći stav zaista deluje kao upozorenje: „Jedna od najosnovnijih pouka dijalektičkog metoda jeste da mogućnosti razvoja određenog načina mišljenja leže predodređene, tako reći suđene, u samoj strukturi njegovih početnih termina i odražavaju karakteristike njegove polazne tačke“ ${ }^{\text {“21 }}$. Pri

dešifrovana tako da se prva sadrži u drugoj („Marks u stvari uključuje Hegela“ [Op. cit, str. 15]).

${ }^{19}$ Op. cit, str. 312.

${ }^{20}$ Fredrik Džejmson, Političko nesvesno, str. 8. Izuzetno je važno, međutim, imati u vidu da je u osnovi diskusije o interpretativnim prednostima marksizma položen stav da je svaki kulturni artefakt kao takav (pa onda eventualno i svaki interpretativni model) u svojoj krajnjoj osnovi determinisan konkretnom istorijom i društvenom stvarnošću. Džejmson to naglašava i na ovaj način: „Bitno je, u stvari, to da marksizam nije samo još jedna teorija istorije, nego je on 'kraj' ili ukidanje teorija istorije uopšte" (Marksizam i forma, str. 325). Ovo ukidanje pluralizma teorija istorije ide ka tome da se pokaže da istorijsko mišljenje kao takvo može imati samo jedan jedinstveni predmet - a to je građansko društvo. „Ali shvatiti da svi imamo jedan zajednički predmet znači biti samo još grublje suočen sa veoma bolnom svesnošću o pravim izvorima klasnog suda i ideološkog izbora“ (Op. cit, str. 326.)

${ }^{21}$ Op. cit., str. 24. 
tome je posebno interesantan Džejmsonov izbor reči kojima se opisuje specifična dijalektička zakonomernost razvoja modela mišljenja, prema našem prevodu sudbina (na engleskom jeziku stoji foreordained ${ }^{22}$ ). Ova reč nije samo uočljiva zbog njenog očiglednog metaforičkog značenja, već nameće pitanje o tome na koji je način kod Džejmsona shvaćeno pitanje determinizma kojim se dijalektička kategorija sama u sebi razvija, odnosno proizilazi iz prethodećih? Džejmson termin kategorija uzima kao oznaku osnovne, dinamične jedinice ili instance na koji je usmeren dijalektički kritički proces. „Ono što nas trenutno interesuje jeste ona kretnja kojom se jedan elemenat - nazovimo ga tehnikom ili strukturom, komponentom, ili ako hoćete kategorijom - izdvaja iz nekog dela da bi se

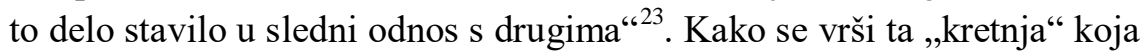
odlučuje u pogledu odabira ovih kategorija?

$\mathrm{S}$ upotrebom termina kategorija, a pogotovo u kombinaciji $\mathrm{s}$ „lapsusom“ o njihovoj predodređenosti, prizvan je iz istorije filozofije modus filozofske kritike koji prethodi Hegelovom. Taj model ne objašnjava vlastite polazišne kategorije, odnosno kriterijume kritike, pod pretpostavkom istoričnosti mišljenja. Štaviše, kategorije za Kanta proizilaze iz same prirode uma, odnosno razuma kao one moći koja operiše čistim pojmovima. Ideje nastaju kao poseban proizvod transformacije tih čistih pojmova od strane uma. One zapravo nastaju dejstvom transcendentalnog privida, koji bi se kod Kanta mogao „optužiti“ da predstavlja, modernim rečnikom rečeno, racionalno izvorište ideologije, odnosno u njegovoj terminologiji „religijske nade“ kao jedine ekstenzije ili modifikacije ,,istorijske svesti“ o kojoj se može govoriti ex principis na osnovu kritike čistog uma. Međutim, ova je nada izvan-istorijski formirana, što u krajnjoj liniji to znači da nijedna posebna istorijska epoha, niti istorijski događaj poput ljudskog stradanja izazvanog pošastima, ratom, migracijama, sušom, nije mogla podstaći istorijsku refleksiju o cilju čovekovog civilizacijskog napretka u strogom filozofskom smislu budući da bi ona, prema Kantu, morala da se kreće u

\footnotetext{
${ }^{22}$ Fredric Jameson, Marxism and Form, p. 9.

${ }^{23}$ F. Džejmson, Marksizam i forma, str. 319.
} 
sferi onoga ex datis ${ }^{24}$. Kao svojevrsna aistorijska svest o istorijskom hodu ljudske civilizacije, nada u svet koji će odgovarati čovekovom savršenstvu kao cilju koji počiva na kraju puta, predstavlja imanentnu posledicu njegove umske prirode, a ne njegovog istorijskog iskustva. Za Hegela, međutim, odabir tih kategorija kojima bi se kritika vodila ne bi mogao da se opravda pozivanjem na aistorijsku prirodu uma, niti pozivanjem na konkretnu istoriju.

Aistorijski karakter Kantove kritike čistog uma vidljiv je i u ovoj dimenziji redukovanja kritičkog posla na istraživanje formi mišljenja i uslova mogućnosti saznanja, to jest transfiguracija kategorija između apriorne i aposteriorne ravni. Ove transcendentalne forme su unapred već dati kriterijum kritike. Aluzija na predodređenost dominantnih kategorija, kao formalnih kriterijuma, u smislu onoga čime dijalektička kritika nužno započinje, mora da se odbrani od ovog prigovora da pri tome primenjuje kriterijum koji nikada ne može na adekvatan način da se odbrani u svojoj imanentnosti samom predmetu kritike. No, da li bi okretanje ka drugoj strani ove dileme, konkretnoj istoriji ili, tradicionalnim rečnikom rečeno, empiriji i „indukovanju“ kategorija kao polazišnih tački kritike predstavljalo bolje rešenje? $\mathrm{S}$ hegelijanske tačke gledišta, to bi predstavljalo anahrono rešenje, odnosno još jedan dodatni stepen pada na pretkantovsko stanovište. Hegel je već relativno rano, u takozvanom jenskom periodu svog filozofskog razvoja, uvideo da bi još manje pouzdan način artikulisanja kritičke procedure počivao na „objektivnosti““ samih istorijskih događaja: „[K]ritička filozofija [je] imala važno negativno dejstvo na teorijske nauke tako što je istakla da ono naučno u njima nije ništa objektivno, već pripada sredini između ništa i realnosti, mešavini bitka i nebitka, da su one samo u empirijskom mnenju“'25.

No, kako zapravo Džejmson razume ključne proceduralne korake dijalektičke kritike? Glavni „narativ“ kako on to vidi, koji je specifičan za dijalektički način filozofiranja je obrtanje krajnosti - na primer, ono što je delovalo kao prepreka, pokazaće se kao prednost ili obrnuto. Prema

${ }^{24} \mathrm{U}$ odeljku o arhitektonici čistog uma, Kant je formulisao razliku između cognitio ex datis i cognitio ex principiis (Kant, I., Sämmtliche Werke, Band 3, S. 550.)

${ }^{25}$ G. W. F. Hegel, Werke, Band 2, S. 436 - 437. 
načinu na koji to Džejmson, za potrebe ove rasprave, pojednostavljuje: u dijalektičkoj analizi se polazi od „zahteva“ da se izdvoji nekolicina, mali broj, faktora kod kojih će biti moguće ispratiti ovo „obrtanje“. Kada Džejmson govori o prethodnom izboru dominantnih kategorija obrazloženje je pragmatično, odnosno reč je jednostavno o strateškom izboru. Međutim, u knjizi Političko nesvesno, gde se dijalektici prilazi iz perspektive njene tekstualne fenomenalnosti, on to objašnjava tako što kaže da bi kritika polazila od pretpostavke ,nataloženih čitalačkih navika i kategorija koje smo razvili iz [tih] nasleđenih interpretacija“'26. Veoma je važno napomenuti da je Džejmsonova analiza dijalektičke kritičke procedure, onako kako je barem izvedena u delima Marksizam i forma $\mathrm{i}$ Političko nesvesno, primarno usmerena na analizu dijalektičkog teksta kao kulturnog artefakta. Pri tome je jednako važno i to da ne postoji nešto poput teksta „po sebi“, odnosno tekst koji bi bio „netaknut“ interpretacijama $\mathrm{i}$ već postojećim kategorijama. Na taj način se „,nataloženost", „,nasleđenost“, ,predodređenost“" kategorija, kao iluzija s kojom se nužno i strateški startuje kako bi bila raspršena, može razumeti u smislu jednog Hegelovog navoda iz Fenomenologije duha: „Svest će svoj odnos prema drugobitku ili svom predmetu odrediti na različite načine, već prema tome, na kom stupnju upravo stoji svetski duh koji postaje svestan sebe. Kako on sebe i svoj predmet neposredno nalazi i određuje, ili kako je on za sebe, zavisi od toga šta je on već postao ili šta

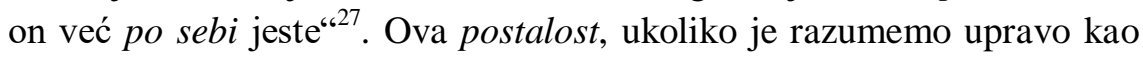
aktualnost koja je istorijski formirana i time, za Hegela, rezultat čovekove slobode, po smislu je isto s onim šta Marks govori o „zaticanju“ određenog nivoa razvitka proizvodnih snaga u Nemačkoj ideologiji ${ }^{28}$.

Međutim, svojevrsna napetost istrajava: s jedne strane, prilikom proučavanja specifičnog slučaja, stoji zahtev za apstraktnošću, odnosno nužnim pojednostavljivanjem, dok s druge strane, stoji upozorenje da bi preterano usložnjavanje vodilo kritiku u ,element konkretne istorije“29. Zahvatati i povezati svaki mogući faktor u procesu dijalektičkog

${ }^{26}$ F. Džejmson, Političko nesvesno, s. 7.

${ }^{27}$ G. W. F. Hegel, Werke, Band 3, S. 181.

${ }^{28}$ K. Marks / F. Engels, Nemačka ideologija, str. 315 - 316.

${ }^{29}$ Op. cit., str. 314. 
razumevanja „uronilo“ bi kritiku u konkretnu istoriju. Pojednostavljenje, ili strateški odabir nekolicine faktora, potrebno je da bi se teoretizovalo „izvan“ ili „iznad“ konkretne istorije. Jedna odluka za pojednostavljivanje ili apstrahovanje faktora ispada, prema Džejmsonu, nužna da se od elementa konkretne istorije dopre do elementa mišljenja. Jednom je već element mišljenja uzet kao polazište na kome je kretanje svake odlučujuće filozofske kategorije bilo prikazano s obzirom na njihovo dijalektičko izvorište i unutrašnje tkivo, a to je naravno Nauka logike. Džejmson će istaći da je Hegel u Nauci logike upravo razradio logičke kategorije u sledu koji je suštinski dijahroničan iako je „samo idealna konstrukcija ${ }^{30 ،}$. S obzirom na tu „idealnost“ prikaza odnosno konstrukcije, u skladu sa poznatom shemom interpretiranja statusa Hegelove filozofije unutar tradicije marksizma, dotičemo se granica moći i korisnosti hegelijanskog modela. Ima li u pozadini ovakvog predstavljanja elemenata dualističkog sučeljavanja Hegela i Marksa ${ }^{31}$ ? Džejmson dakako ističe nepomirljive razlike jednog i drugog modela dijalektike, ali insistira više puta da se oni međusobno ne isključuju ${ }^{32}$.

Ukoliko je ovde potvrđena Marksova dijagnoza iluzija hegelijanskog metoda - da je misaono reprodukovanje zamenilo zbiljsko

${ }^{30}$ Op. cit., str. 329.

31 Ova senka njihovog dualizma kod Džejmsona se može razumeti i kao polemički momenat, odnosno tako da je uslovljen Džejmsonovim odnošenjem spram Altiserovog shvatanja. Njegov odgovor Altiseru zapravo bi trebalo potražiti u Džejmsonovom konačnom okretanju Sartrovom filozofskom projektu kao završnom kamenu projekta dijalektičke kritike, a ne više Hegelu. To se najbolje vidi na osnovu stavova poput ovog: „Suštinska vrednost Sartrove knjige [Kritika dijalektičkog uma - prim. N. J.] za dijalektičku književnu kritiku leži u načinu na koji ona postavlja problem bitan za svaku marksističku teoriju, problem posredovanja: to jest pitanje kako mi prelazimo sa jednog plana društvenog života, na drugi, sa psihološkog na socijalni, a i sa socijalnog na ekonomski. Kakav je odnos ideologije, da i ne spominjemo samo umetničko delo, prema bitnijoj socijalnoj i istorijskoj stvarnosti grupa u sukobu, i kako treba razumeti ove poslednje ako želimo da sagledamo kulturne predmete kao socijalne čine, istovremeno prikrivene i providne?" (Fredrik Džejmson, Marksizam i forma, str. 14). U knjizi Političko nesvesno u polemici s Altiserom pozivaće se takođe na nesporazume u vezi s problemom posredovanja (Fredrik Džejmson, Političko nesvesno, str. 43 -44).

${ }^{32}$ Op. cit., str. 343. 
produkovanje konkretno $^{33}$ - hegelijanstvo pri ovoj Džejmsonovoj analizi njegove korisnosti stoji neubedljivo kao apstraktna teorijska artikulacija. „Može se, u stvari, tvrditi da takav dijahronični sled, bez obzira koliko je stvarno istorijski ili vremenski, nužno ostaje apstraktan, jer je, on zapravo, samo idealni presek egzistencijalne gustine konkretne istorije izdvajanje samo jednog plana ili nivoa stvarnosti u kome se stvarnost shvata i kao idealni zbir svih takvih planova i kao ona krajnja, nezamisliva totalnost koja se nikada ne može rekonstruisati samo takvim sabiranjem, samo delovanjem čiste misli“‘34. Zatim: „Otuda je završni momenat $\mathrm{u}$ procesu dijalektičke analize onaj u kojem se model trudi da se vrati onom konkretnom elementu iz koga je potekao, da ukine sebe kao iluziju autonomnosti $\mathrm{i}$ da se rastvori u istoriju, pružajući pri tome trenutačan pogled na stvarnost kao konkretnu celinu“35. S naizgled pragmatičnom odlukom da se stvari priđe na jedan apstrahujući način, nastupa dijalektički mehanizam ukidanja prvobitne naivnosti i jednostranosti - naivnosti koja se ogledala u ,iluziji autonomije“ misli u odnosu na stvarnost, filozofije u odnosu na konkretnu istoriju. Možda se može reći da je najiluzornija sama ovakva dualistička postavka. Na jednom drugom mestu, Džejmson će istaći dualizam kao karakteristiku strukture ideoloških predstava uopšte. On kaže: „Dualizam je, verujem, snažna forma ideologije kao takva, koja dakako može maskirati svoju dualnu strukturu u bilo koju komplikovanu supstituciju. To je tako, tvrdio bih, jer predstavlja krajnju formu etičke binarnosti, koja je time uvek krišom na delu unutar ideologije“636!

\section{KRITIKA VODI U POLITIKU, HERMENEUTIKA U?}

No, ukoliko se stvar ne gleda toliko poopšteno, već u nešto konkretnijem kontekstu književniih analiza koje su date unutar Marksizma i forme, možemo videti još jednu stranu dualizma, dualizam kritike i hermeneutike. Među naslovima poglavlja te knjige nalazimo na

\footnotetext{
${ }^{33}$ Karl Marx, Temelji slobode, str. 27.

${ }^{34}$ Op. cit., str. 316.

35 Loc. cit.

${ }^{36}$ Fredric Jameson, Valences of the Dialectic, p. 198.
} 
formulacije „hegelijanska kritika“ i „marksistička hermeneutika“, dva misaona modusa koja se ovim delom zagovaraju. Kritika u svom hegelijanskom vidu, a hermeneutika u marksističkom, predstavljaju konstitutivni deo celovitog „dijalektičkog mišljenja“ (u knjizi Političko nesvnesno upotrebljava termin „metakomentar ${ }^{\text {“37 }}$ ), kao jedne procedure koja bi mogla dopustiti još jednoj problematičnoj binarnosti objašnjenje/razumevanje - da se zaoštri do dijalektičke realizacije njihovih suprotnosti i raspršivanja njene iluzornosti. Kao što je već naznačeno, hegelijanska kritika se poistovećuje s onakvom analizom koja polazi od relativno malog broja faktora, a zatim se posmatraju njihovi međusobni odnosi, budući da je primarna karakteristika tih faktora njihova relacija (,paralelni sledovi“, „koji otvoreno privlače pažnju na sebe komparacijom tačku po tačku“ - reklo bi se da su ovo dualizmi, zar ne?). Ovaj uporedni, komparativni aspekt je izuzetno važan, jer omogućava da „saznamo šta je neka stvar putem istovremenog saznanja onoga šta ona nije ${ }^{\text {“38 }}$. Rezultat ili dobitak je taj da se određena pojava sagleda, u svojoj ukinutoj samostalnosti, kao ,pojedinačni vezni deo u jedinstvenom artikulisanom procesu““39. Dijalektičkom kritikom se u odnosu na predmet kritike, posluživši se habermasovskom formulacijom, krećemo izvan njega ${ }^{40}$, a Džejmsonovim rečnikom, sagledavamo ga kao ukinutog u vlastitoj samostalnosti i kao deo jednog višeg reda razumevanja. Izdvajanje ovih faktora odnosno kategorija i razvijanje „dijahroničnog" sleda, konstrukcije koja se u kategoriji podrazumeva i koja predstavlja razradu samih kategorija - dva su uvodna momenta dijalektičke kritike, kaže Džejmson, u njenom hegelijanskom vidu ${ }^{41}$. Na mestu kada govori o konstrukciji kao razrađivanju i ekspoziciji kategorije, Džejmson će istaći kako se ta konstrukcija može „protumačiti: upravo time ona relativno uprošćena ideja koju smo izabrali za polaznu tačku može biti ispravljena i adekvatnije utemeljena u konkretnoj istoriji... Ali tu je već blizu trenutak u kome taj dijahronički sled pod

\footnotetext{
${ }^{37}$ Fredrik Džejmson, Političko nesvesno, str. 8.

${ }^{38}$ Fredrik Džejmson, Marksizam i forma, str. 315..

${ }^{39}$ Fredric Jameson, Marxism and Form, p. 312.

${ }^{40}$ Vidi: Steven Helmling, The Success and Failure of Fredric Jameson, p. 51.

${ }^{41}$ Fredrik Džejmson, Marksizam i forma, str. 323.
} 
vlastitim zamahom skreće, najavljujući svoje konačno ukidanje i povratak samom konkretnom “42. Kritika bi dakle sebe morala ukinuti u razumevanju koje je u sprezi s konkretnom istorijom. Kao transparentno idealistički, Hegelov model omogućuje vlastitim ukidanjem da se razreši dualizam „svesti i života“ (filozofije i istorije, hegelijanstva i marksizma) tako da u krajnjem život određuje svest. Na taj način bi, samim dijalektičkim obrtanjem narativa, bio razrešen i dualizam Hegel - Marks, tako da je Hegel sadržan u Marksu, a kritika u razumevanju ${ }^{43}$.

U poglavlju u kome Džejmson obrazlaže duh marksističke hermeneutike, ona je shvaćena na jedan poseban način kao „u stvari politička disciplina koja pruža sredstva za održavanje kontakta sa samim izvorima revolucionarne energije u nekom vremenu stagnacije, za potajno, podzemno očuvanje samog pojma slobode u geološkim vekovima ugnjetavanja““44. Marksistička hermeneutika je na strani konkretne istorije, empirijskih realnosti koje tek na osnovu ili putem (samoukidanja) idealističkih konstrukcija hegelijanske kritike može da vrati totalizujućem materijalističkom razumevanju „iznutra“, ali pročišćeno od ideoloških iskrivljenja. Drugim rečima, materijalizam

\footnotetext{
${ }^{42}$ Op. cit., str. $322-323$.

43 Potpunosti radi, potrebno je reći i to da Džejmson govori i o marksističkoj kritici u smislu kritike ideologije: „Zato je dijalektička misao po samoj svojoj strukturi svest o sebi, i može se opisati kao pokušaj da se misli o samom objektu i istovremeno o našem procesu mišljenja... U toj svetlosti, razlika između Hegelove i marksističke dijalektike može se odrediti prema vrsti svesti o sebi koju sadrži. U Hegela je ta svest relativno logička, ona sadrži osećanje povezanosti takvih čisto intelektualnih kategorija kao što su subjekt i objekt, kvalitet i kvantitet, ograničenost i beskrajnost, i tako dalje; mislilac tu shvata kako njegovi vlastiti namerni procesi mišljenja, a i same forme problema od kojih polazi, ograničavaju rezultate njegovog mišljenja. Za marksističku dijalektiku pak, svest o sebi kojoj ona teži jeste svest o misliočevom položaju u društvu i istoriji i o granicama koje toj svesti nameće njegov klasni položaj ukratko o ideološkoj i situacijskoj prirodi svakog mišljenja i o tome da su problemi u početku pronađeni““ (Fredrik Džejmson, Marksizam i forma, str. 343). Takođe, ovde vredi napomenuti i stav Stivena Helmlinga, da će se u binarnosti koju na koncu kritički ethos uopšte podrazumeva, kao binarnost subjekta i objekta, videti razlog Džejmsonove vremenom sve snažnije podozrivosti prema „kritici“ i izostajanja ovog termina iz njegovih kasnijih tekstova. Steven Helmling, The Success and Failure of Fredric Jameson, p. 52.

${ }^{44}$ Fredrik Džejmson, Marksizam i forma, str. 98.
} 
razumevanja, solidarnost razumevanja, moguće je tek na osnovu idealizma. Hegelijanski je model kritike „obeležen onim konačnim i neizbežnim, prisutnim u samoj njegovoj strukturi, kretanjem ka svom konačnom raspadu, pri čemu on, međutim, razvija iz sebe marksistički

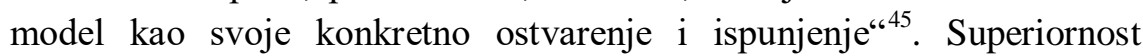
hegelijanskog modela kritike, odnosno idealizma, počiva dakle u ovoj tendenciji ka samoukidanju i, konačno, prema tome kako to Džejmson postavlja, ovo samoukidanje bi ujedno bilo i realizovanje latentne hermeneutičke tendencije Hegelove dijalektike.

$\mathrm{Na}$ koncu se pokazalo to da čitav ovaj pokušaj plediranja slučaja značaja hegelijanske kritike za marksističko razumevanje ide za relativno tradicionalnim (Marksovim) shvatanjem spekulativne konstrukcije, koja je demistifikovana kao izaz čovekovog otuđenja, tačnije supstancijalizovanja onoga idealnog i njegove supstitucije za ono realno. S obzirom da je takvo razumevanje učinka hegelijanske dijalektike deo „utvrđene“ tradicije, može se, primenom dijalektičke perspektive na nju samu, pledirati u njeno ime time što u sebi sadrži jednostavan mehanizam prevladavanja same sebe „Iluzije Hegelovog idealizma nisu toliko rezultat društvene i političke mistifikacije koliko onog trajno opasno nesvesnog egocentrizma koji uvek lebdi nad ljudskim umom... strukturalna samoobmana koja potiče iz protivrečnosti između misli kao procesa umiverzalizovanja i prirode našeg duha kao pojedinačno postojećeg... njemu su podjednako podložni i ,idealisti““ i „materijalisti“, jer on znači prosto zaboravljanje našeg vlastitog položaja kao

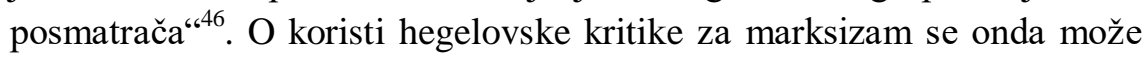
još govoriti i kao jednom intelektualnom dobru koje predstavlja mehanizam odbrane od zapadanja u tu strukturalnu samoobmanu čak i na stanovištu marksizma. Konačno, „čim možemo osetiti vlastitu misao kao istorijsku akciju jednaku objektima proučavanja, čim smo kadri da uračunamo i vlastitu posmatračku poziciju u proces kritičkog mišljenja, Hegelova protivrečnost je prevaziđena... po svom shvatanju svih događaja, mentalnih i drugih, kao duboko istorijskih i situacijskih, Marksova misao predstavlja napredak u odnosu na Hegelovu, koja je

\footnotetext{
${ }^{45}$ Op. cit., str. 330.

${ }^{46}$ Op. cit., str. 369.
} 
filozofu istorije ostavljala jedinstven položaj van istorije i zato nije mogla da shvati pojam postojanja u situaciji u njegovim najparadoksalnijim dimenzijama"“47.

Ukoliko iz ovih redova, prema tome šta tvrde prima facie, može da se izvuče bilo šta mimo fojerbahovske kritike Hegelove spekulativne metode, koja je bila karakteristična i za takozvanog mladog Marksa, to bi valjalo raditi preko i na osnovu neporecive činjenice da je Hegelova filozofija i te kako imala sluha za istorijsku uslovljenost mišljenja. Nema te misli koja nije uslovljena na ovaj ili onaj način istorijskim razvojem obrazovanosti $i$ opšte misaone kulture ${ }^{48}$. Prevaziđenost Hegelove filozofije jednako je onda istorijska, ukoliko se to može tako tvrditi, a ne suštinska. Istorijska je u onoj meri u kojoj je skoro pa nerazumljiva ukoliko se ukloni društveno-istorijski kontekst elemenata njegovog učenja (ponajviše onog njegovog učenja u kome je $i$ reč o karakteristikama ekonomsko-političke istorije građanskog društva, a to je filozofija prava). Ukoliko bi se pošlo drugačijim putem od Džejmsonovog u proceni značaja hegelijanske kritike za marksizam, valjalo bi poslušati same hegelijanske metodološke podsticaje. Prema Hegelu, kritička odnosno „oštra refleksija“ pre svega mora biti sposobna da uoči i formuliše protivrečnost ${ }^{49}$ u svojoj konkretnoj istorijskog situaciji. Onaj interpretativni postupak koji ima za cilj postizanje razumevanja, polazeći od inicijalnog nesporazuma koje bi trebalo prevazići zarad „velikodušnog pomirenja“, može biti optužen za omekšavanje protivrečja koje nije samo filozofski fantazam, već nešto realno u socijalnom i političkom smislu. Upravo bi se kao filozofska ili hermeneutička mistifikacija moglo pokazati ovo plediranje na

\footnotetext{
${ }^{47}$ Op. cit., str. 363.

${ }^{48}$ U svojoj kasnijoj studiji Hegelove Fenomenologije duha pod naslovom The Hegel Variations, Džejmson će dovesti u vezu Hegelov pojam duha i Marksov pojam „opšteg intelekta“ s obzirom na zajedničku im pretpostavku socijalne transformacije u svesti i mentalitetu. Fredric Jameson, Hegel Variations, p. 4.

49 Referenca preuzeta iz: Domenico Losurdo, Hegel and The Freedom of Moderns, p. 28. Ova knjiga u celosti predstavlja odličan primer kritičke analize Hegelove filozofije kao kulturnog artefakta upravo sa stanovišta političkih borbi koje se hrane protivrečnim interpretacijama njegovog opusa. Pojmovno sučeljavanje ,interpretativnog nesporazuma” i ,protivrečja” zahvaljujem jednom podnaslovu iz nje (p. 27)!
} 
razumevanje kao korigovanje „nesporazuma“, raspršivanje „iluzije“, kako bi se pripremila solidarnost. „Uočavanje i formulisanje protivrečnosti“, ukoliko se razume kao zadatak hegelijanske kritike protivrečnosti a ne samo relacija, srazmer snaga i komparativna analiza faktora, bilo bi znatno korisnije marksizmu, jer je u protivrečnostima i suprotstavljenim interpretacijama (što je ionako $u$ skladu $\mathrm{s}$ Džejmsonovim osnovnim tezama) prisutan politički kontrast kao takav koji se hrani istim tekstovima, istim kulturnim fenomenima i artefaktima. Više će se o prirodi tih povoda, odnosno tekstovima kao društvenim i istorijskim proizvodima, naučiti time što će se otkriti mehanizam proizvodnje protivrečja koji je izražen u njima ili njima podsticajan za rasplamsavanje političke a ne samo ideološke borbe (neka kao primer bude taj što su Marks i Engels shvatali Hegelovu Filozofiju prava kao zagovaranje konstitutivne monarhije), nego što će se uklapati jedan tekst idealnom konstrukcijom u širi istorijski kontekst.

Sem toga, zadatak je marksističkog razumevanja u delu Političko nesvesno ostao otvoren. Kada tražimo neko pozitivno učenje o „novim oblicima kolektivnog mišljenja i kolektivne kulture", kao ono što bi trebalo da bude zadatak samog „metakomentara“, naići ćemo na, kako to sam Džejmson kaže, ,jednu praznu stolicu, rezervisanu za neku još neostvarenu, kolektivnu i decentralizovanu kulturnu proizvodnju budućnosti“汭. Nije li na koncu zaista legitimno pitati može li se dijalektička kritika statuirati unutar marksizma na neki drugi način koji bi omogućio mobilisanje političkih energija i nešto više obavezujuću artikulaciju mogućih modela kolektivnog mišljenja i kulture? U tom izmenjenom kontekstu onda bi valjalo ponovo postaviti pitanje o interpretiranju Hegelove filozofije. Dijalektička kritika hegelijanskog tipa tretira se tako kao da vazda operiše sa stanovišta subjektivnog idealizma, što je prigovor koji se ne može istini za volju uputiti Hegelovoj spekulativnoj filozofiji na jedan samorazumljiv način. Ukoliko je na koncu sam Marks hegelijansku kritiku razumeo u tom ključu subjektivnoidealističke konstrukcije ${ }^{51}$, to nije nužno obavezujuće i za predstavnike savremenog marksizma u izmenjenim istorijskim okolnostima, pogotovo

\footnotetext{
${ }^{50}$ Fredrik Džejmson, Političko nesvesno, str. 9.

${ }^{51}$ F. Engels, K. Marks, Sveta porodica, str. 89.
} 
ako je osnovna tema, koju ovaj članak poštuje, uslovljenost mišljenja istorijom. Potrebno je još ovo reći na temu toga da je Džejmson deo tradicije čiji filozofski sistemi i interesovanja preslikavaju istorijsku situaciju očaja i presahlosti političkih energija. Korisnost jednog od radikalnih filozofskih načina tematizovanja istorijske uslovljenosti čovekovog mišljenja i delanja svodi se na samoukidanje dijalektike u hermeneutici, kritike u razumevanju, čime se dobilo (samo) to da se poprište borbe pomera ili solidifikuje unutar intelektualne sfere, jer je rešeno da politička borba doživi realizaciju i ukidanje u interpretativnoj solidarnosti (pomirenju kome bi vredelo uputiti prigovor da je barem isto onako intelektualno, to jest idealna konstrukcija, kako se to tradicionalno podrazumevalo o Hegelovom konceptu Versöhnung). I pored sve ubedljivosti argumentacije o interpretativnoj superiornosti marksizma, kao da je zaboravljena politička vita activa, jer je već kod mladog Marksa određena „putanja“ prevladavanja hegelijanske kritike (filozofije) u političkoj borbi (revoluciji) ${ }^{52}$.

\section{LITERATURA}

[Ed.] Kouvelakis, Sthatis / Bidet, Jaques, Critical Companion to Contemporary Marxism, Leiden, Boston, Brill, 2008.

Anderson, Perry, Considerations on Western Marxism,London, Verso, 1976.

Anderson, Perry, The Origins of Postmodernism, London, New York, Verso, 1999.

Džejmson, Fredrik, Marksizam i forma, Beograd, Nolit, 1974.

Džejmson, Fredrik, Političko nesvesno, Beograd, Rad, 1984.

Hegel, Georg Wilhelm Friedrich, Werke, Frankfurt am Main: Suhrkamp Verlag, 1971 - 1979.

Jameson, Fredric, Marxism and Form, New Jersey, Princeton, 1977.

Jameson, Fredric, The Hegel Variations, London, Verso, 2010.

Jameson, Fredric, Valences of the Dialectic, London, Verso, 2009.

Kant, Immanuel, Sämmtliche Werke, Leipzig: Leopold Voss, 1867 - 1868.

Losurdo, Domenico, Hegel and the Freedom of Moderns, Duke University Press, Durham and London 2004.

Marks, K., Engels, F., Sveta porodica, Beograd, Kultura, 1964.

${ }^{52}$ K. Marx, F. Engels, Prilog kritici Hegelove filozofije prava, str. 136. 
Marx, K., Engels, F., „Nemačka ideologija“, „Prilog kritici Hegelove filozofije prava“" u: Glavni rodavi Marxa i Engelsa, Zagreb, Stvarnost, 1979.

Marx, Karl, Temelji slobode. Osnovi kritike političke ekonomije, Zagreb, Naprijed, 1977.

Steven Helmling, The Success and Failure of Fredric Jameson, Albany, State University of New York Press, 2001.

\author{
NEVENA JEVTIĆ \\ University of Novi Sad, Faculty of Philosophy
}

\title{
FREDRIC JAMESON'S CONCEPT OF DIALECTICAL CRITIQUE
}

\begin{abstract}
This paper intends to present the basic structure of Jameson's concept of dialectical critique in the manner it is developed in Marxism and Form and Political Unconscious. Author's intention is to give an analysis of specific constitutive dualism by which Jameson approaches the tradition of dialectical thinking, such as 'philosophy - history', 'Hegelianism - Marxism', 'critique understanding', and its abolition. Starting from the fact of this concept's immense analytical power, this paper endeavors to affirm Jameson's project of revitalization of critique as an unsurpassed mode of Marxist intervention within the world of late capitalism.
\end{abstract}

Keywords: West Marxism, Dialectical Critique, Jameson, Hegel, Marx

Primljeno: 29.2.2020.

Prihvaćeno: 6.5 .2020$. 